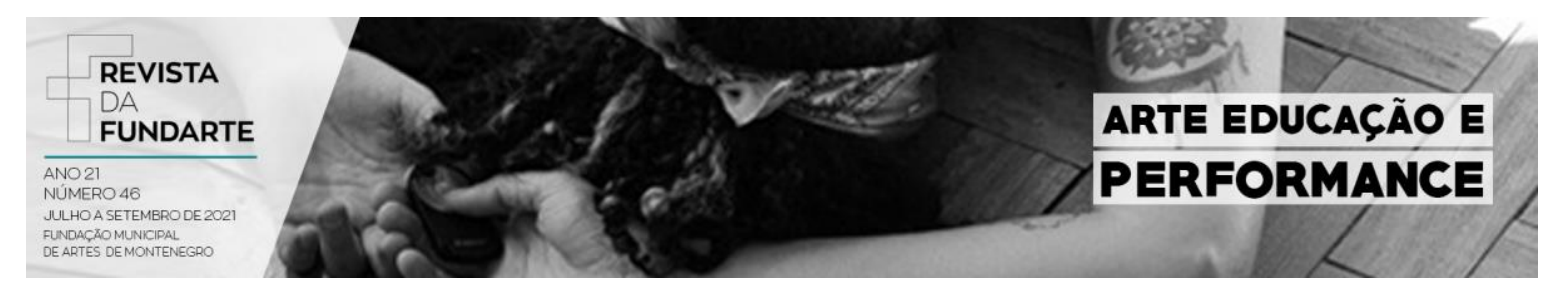

\title{
O DESENHO DA CENA EM UM PROCESSO COLABORATIVO: INVESTIGAÇÕES ACERCA DA CENOGRAFIA PERFORMATIVA
}

\author{
Mateus Junior Fazzioni \\ Marcia Berselli
}

DOI: http://dx.doi.org/10.19179\%2F2319-0868.792

FAZZIONI, Mateus Junior ; BERSELLI, Marcia . O desenho da cena em um processo colaborativo: investigações acerca da cenografia performativa. Revista da FUNDARTE. Montenegro, p.01-22, ano 21, no 46, setembro de 2021.

Disponível em: http://seer.fundarte.rs.gov.br/index.php/RevistadaFundarte/issue/archive $>30$ de setembro de 2021. 


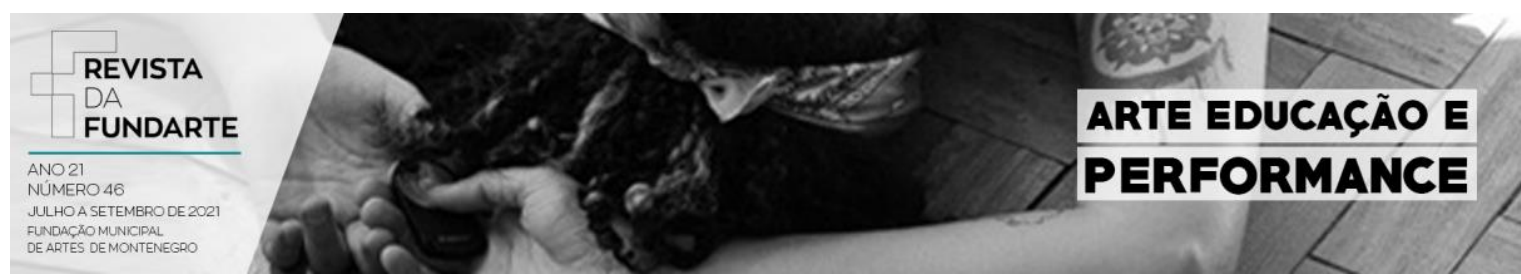

\title{
O DESENHO DA CENA EM UM PROCESSO COLABORATIVO: INVESTIGAÇÕES ACERCA DA CENOGRAFIA PERFORMATIVA
}

\author{
Mateus Junior Fazzioni ${ }^{1}$
}

Marcia Berselli2

\begin{abstract}
Resumo: $O$ presente texto analisa a atuação do designer de cena em um processo criativo desenvolvido em modo colaborativo em ambiente universitário. No desenvolvimento do acontecimento cênico "Antes de falar já não se ouve" (2019) cada um dos agentes assumiu diferentes funções artísticas na cena propondo explorações por meio de workshops de criação. Assim, o objetivo do artigo é investigar como ocorre a concepção do desenho da cena pelo artista designer de cena em um processo colaborativo, levando em conta as especificidades desse modo de articulação dos artistas que prima pela horizontalidade das hierarquias. As reflexões aqui apresentadas buscam investigar os indícios de uma cenografia performativa por meio da ética e estética implicadas no processo criativo.
\end{abstract}

Palavras-chave: Designer de cena; Processo colaborativo; Desenho da cena.

\section{PERFORMANCE DESIGN IN A COLLABORATIVE PROCESS: INVESTIGATIONS ABOUT OF THE SCENOGRAPHY PERFORMATIVE}

\begin{abstract}
This paper analyzes the role of the scene designer in a creative process developed in a collaborative way at the university environment. In the development of the scenic event "Antes de falar já não se ouve" (2019) each of the agents took on different artistic functions in the scene, proposing explorations through creative workshops. Thus, the objective of the article is to investigate how the scene design conception by the scene designer artist occurs in a collaborative process, taking into account the specificities of this way of articulating the artists that strives for the horizontality of the hierarchies. The reflections presented here seek to investigate the evidence of a performative scenography through the ethics and aesthetics involved in the creative process.
\end{abstract}

Keywords: Scene designer; Collaborative process; Performance design.

\footnotetext{
1 Mestrando em Teatro no Programa de Pós-Graduação em Teatro (PPGT/UDESC). Licenciado em Teatro pela Universidade Federal de Santa Maria (UFSM/2021). Atualmente atua como arte-educador na Rede Estadual de Ensino de Santa Catarina (SED-SC) e como pesquisador no Grupo de Estudos sobre Teatro e Infâncias (GETIs) e no Grupo de Pesquisa Teatro Flexível: práticas cênicas e acessibilidade (CNPq/UFSM). Atua também como performer pesquisador no Laboratório de Criação (LACRI/CNPq) e no Grupo performATIVAS. Artista da cena e Educador. Tem pesquisas voltadas para teatro, performance, processos colaborativos, pedagogia das artes cênicas, estudos da infância e estudos queer. fazzionimateus@gmail.com / orcid.org/0000-0001-6457-655X.

2 Professora do Departamento de Artes Cênicas da Universidade Federal de Santa Maria. Líder do Grupo de Pesquisa Teatro Flexível: Práticas Cênicas e Acessibilidade (CNPq/UFSM) e do Laboratório de Criação (LACRI/CNPq). Coordenadora do Programa de Extensão Práticas Cênicas, escola e acessibilidade. Artista da cena. marcia.berselli@ufsm.br / orcid.org/0000-0002-2731-1373.
}

FAZZIONI, Mateus Junior ; BERSELLI, Marcia . O desenho da cena em um processo colaborativo: investigações acerca da cenografia performativa. Revista da FUNDARTE. Montenegro, p.01-22, ano 21, no 46, setembro de 2021.

Disponível em: http://seer.fundarte.rs.gov.br/index.php/RevistadaFundarte/issue/archive $>30$ de setembro de 2021. 


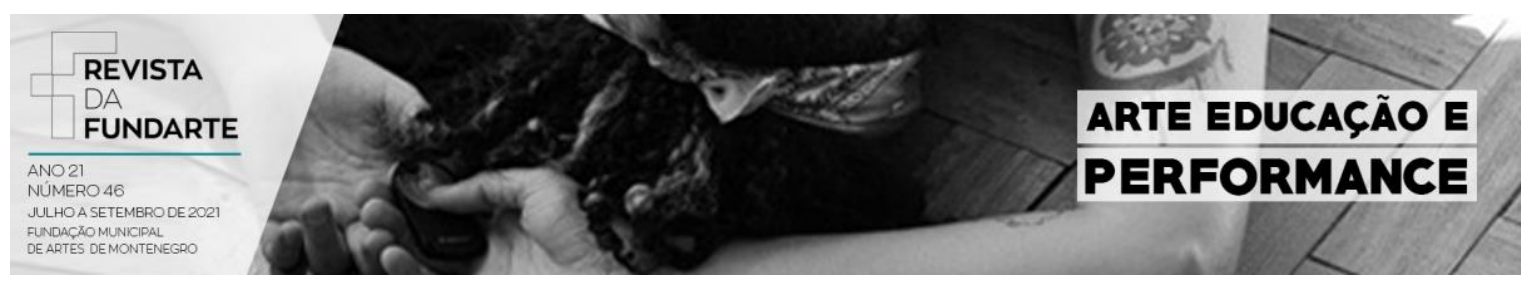

\section{Primeiras aproximações}

Entre as décadas de 1960 e 1970, após as duas grandes guerras mundiais e em meio a regimes ditatoriais na América Latina, artistas inspirados por um pensamento utópico e revolucionário, começaram a propor experimentos de ruptura aos padrões estéticos impostos pela arte moderna. Essas manifestações artísticas híbridas deram início ao que chamamos hoje de arte contemporânea.

Foi a partir desses experimentos que relacionavam teatro e performance que Hans-Thies Lehmann formulou sua tese intitulada Teatro Pós-Dramático (1999) a respeito do então teatro contemporâneo realizado no ocidente, mais precisamente na Europa. Nos estudos a respeito do teatro pós-dramático, Lehmann retoma a obra Teoria do drama moderno (2001) de Peter Szondi, a fim de analisar e problematizar a desconstrução das formas teatrais, para assim tecer o seu conceito de teatro pósdramático.

Para Lehmann, o pós-dramático engloba uma série de formas diferentes entre si, as quais têm como relação em comum, apenas, uma história de ligação com o teatro dramático. Assim, o teatro pós-dramático é um "termo guarda-chuva" composto por "[...] muitíssimas formas teatrais em processo de transformação [...] muitos fenômenos, muitas vezes opostos entre si" (LEHMANN, 2013, p. 251).

O termo se tornou tão amplo a partir dos anos 2000 que pode acabar sendo banalizado em alguns campos teóricos, no sentido de que as fronteiras artísticas estão tão frágeis e mal delimitadas, que já não se sabe mais o que é teatro e o que é performance. E sobre isso o autor argumenta "[...] não há a necessidade de se estabelecer uma linha divisória clara entre o teatro e a performance" (LEHMANN, 2013, p. 875). Mas tais afirmações do autor, trouxeram à tona alguns tensionamentos por parte de alguns teóricos do teatro, a respeito da fusão entre teatro e performance.

Esse é o caso de Josette Féral, que apesar de reconhecer a aproximação entre teatro e performance nos experimentos dos anos 60 e 70, busca delimitar em seus estudos o que especificamente diferencia a linguagem teatral da performance $e$ das demais artes cênicas. A partir disso, a autora vai propor a utilização do termo

FAZZIONI, Mateus Junior; BERSELLI, Marcia . O desenho da cena em um processo colaborativo: investigações acerca da cenografia performativa. Revista da FUNDARTE. Montenegro, p.01-22, ano 21, no 46, setembro de 2021.

Disponível em: http://seer.fundarte.rs.gov.br/index.php/RevistadaFundarte/issue/archive $>30$ de setembro de 2021. 


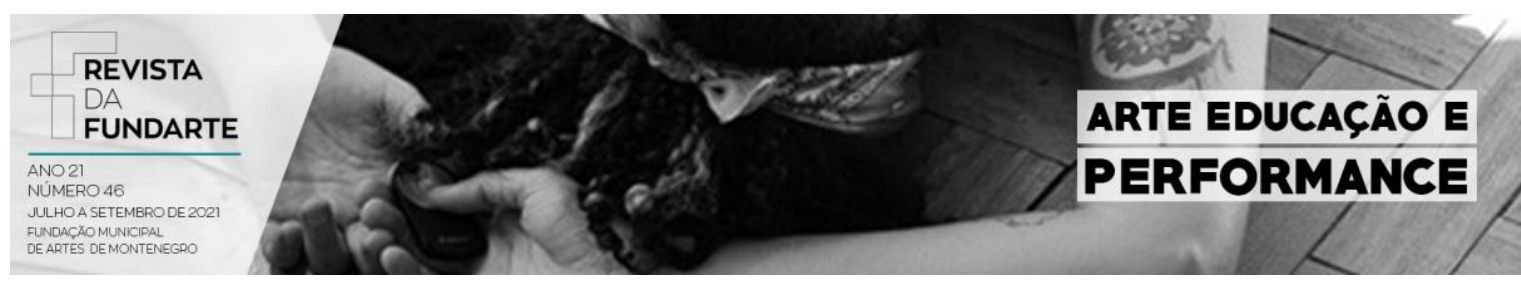

Teatro Performativo para designar as manifestações artísticas teatrais contemporâneas. Isso porque, segundo a autora, todas as práticas artísticas presentes nesse momento de diversidade carregam em seu funcionamento tanto uma noção de teatralidade como de performatividade.

Apesar dos tensionamentos entre Féral e Lehmann é inevitável reconhecer que as manifestações artísticas da segunda metade do século XX proporcionaram outros modos de pensar e fazer teatro. Nesse contexto, surgiram também metodologias de criação menos hierárquicas e mais horizontais, em que os agentes criativos passaram a ter autonomia de proposição e criação, e da mesma forma puderam assumir diversas funções no processo criativo. Esse é o caso dos processos colaborativos ou coletivos nos quais a obra tem a autoria compartilhada.

Tendo em vista esses modos de criação compartilhados, em 2019 os alunos da turma de Montagem teatral I e II do curso de Licenciatura em Teatro da Universidade Federal de Santa Maria (UFSM) ${ }^{3}$, iniciaram a criação do acontecimento cênico "Antes de falar já não se ouve", pesquisando a abordagem de criação em modo colaborativo. Os estudantes tiveram a possibilidade de investigar funções artísticas de seu interesse no processo criativo, nas quais os mesmos assumiram autonomia propositiva e criadora.

Durante o processo de criação, alguns pontos a respeito do processo colaborativo, que era desconhecido pelo grupo de estudantes até então, chamaram nossa atenção. Por exemplo: como se dá a articulação das criações em um processo no qual todos têm a possibilidade de intervir e, da mesma forma, como cada agente organiza os seus interesses e proposições juntamente com o que surge na criação e nas proposições das demais funções artísticas.

Nessa perspectiva, busca-se discutir, no presente texto, como o processo colaborativo se constituiu dentro de uma disciplina de graduação, e como a criação artística se desenvolveu por meio das funções artísticas assumidas pelos estudantes e pelos workshops propostos por cada agente criador. Especificamente, busca-se

\footnotetext{
${ }^{3}$ Universidade Federal de Santa Maria (UFSM), localizada na cidade de Santa Maria - RS.
}

FAZZIONI, Mateus Junior; BERSELLI, Marcia . O desenho da cena em um processo colaborativo: investigações acerca da cenografia performativa. Revista da FUNDARTE. Montenegro, p.01-22, ano 21, ํㅡ 46, setembro de 2021.

Disponível em: http://seer.fundarte.rs.gov.br/index.php/RevistadaFundarte/issue/archive $>30$ de setembro de 2021. 


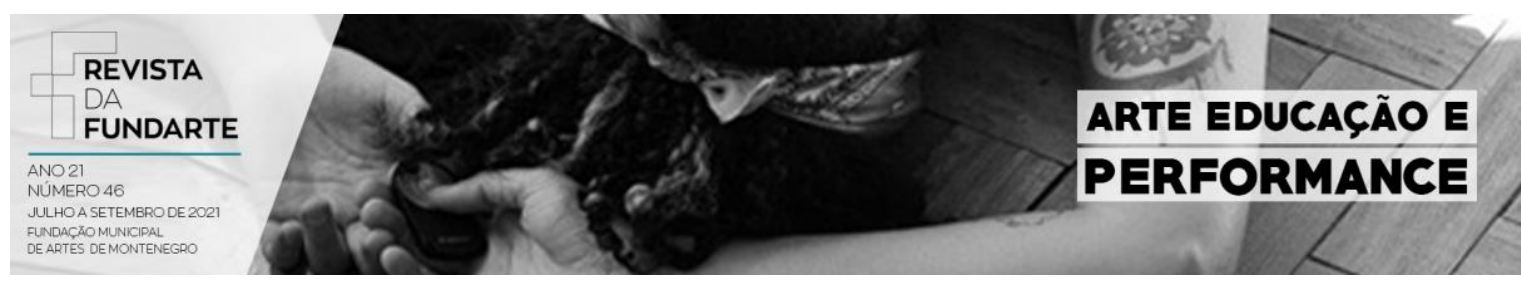

compreender como se dá a articulação do desenho da cena pela figura do designer de cena em um processo colaborativo em que esse tem de relacionar os seus interesses com as demais criações e ideias que surgem no processo.

Essa investigação sobre a criação de um acontecimento cênico operado em modo colaborativo implica levantar uma série de questões éticas, políticas e poéticas, uma vez que tal prática renuncia a centralidade de uma única figura e passa a operar na perspectiva da autoria compartilhada por um coletivo.

Relações entre a performatividade e a teatralidade

$O$ que distingue o teatro dos outros gêneros e, mais ainda, o que o diferencia das outras artes do espetáculo, particularmente da dança, da performance e das artes multimídia? (FÉRAL, 2015, p. 81).

Buscando responder a essa pergunta, Josette Féral entende uma forte ligação entre as manifestações teatrais das décadas de 60 e $70 \mathrm{com}$ os elementos da performance, mas, contrariando Lehmann, a autora busca entender "o que diferencia o teatro das outras artes do espetáculo". Para isso, ela irá propor a utilização do termo Teatro Performativo, uma vez que, para Féral, "[...] seria mais justo chamar este teatro de 'performativo', pois a noção de performatividade está no centro de seu funcionamento" (FÉRAL, 2009, p. 197).

A partir da compreensão dos Performances Studies, apresentados por Richard Schechner, Féral percebe que os experimentos teatrais que tomaram a cena na segunda metade do século XX eram repletos de ações performativas e, nesse caso, de performatividade. Os Estudos da Performance definem a performance como "ação", e dessa forma se dedicam aos estudos das ações. A partir desses estudos percebeu-se que, tanto os comportamentos humanos quanto as práticas artísticas podem ser entendidas como performance, pois evocam outros tipos de ação: o ser/estar a partir da existência, o fazer desempenhando atividades, e o mostrar o que se faz que consiste em performar e exibir uma ação (FÉRAL, 2009).

FAZZIONI, Mateus Junior ; BERSELLI, Marcia . O desenho da cena em um processo colaborativo: investigações acerca da cenografia performativa. Revista da FUNDARTE. Montenegro, p.01-22, ano $21, n^{\circ}=46$, setembro de 2021.

Disponível em: http://seer.fundarte.rs.gov.br/index.php/RevistadaFundarte/issue/archive $>30$ de setembro de 2021. 


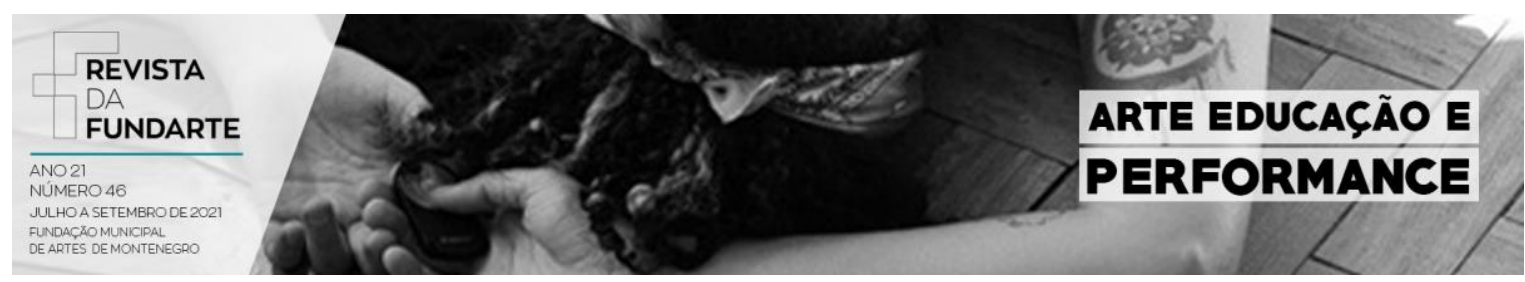

Tendo em vista os Estudos da Performance, a autora entende que a performatividade "[...] não é um fim em si mesmo, uma realidade concreta ou acabada mas um processo" (FÉRAL, 2009, p. 66), um conceito maleável e flexível que, assim como a performance, segundo Schechner (2006), pode estar em todas as coisas, desde ações cotidianas até nos objetos vistos como performance.

Se a performance é entendida como a ação de fazer e re-fazer comportamentos, repletos de performatividade, nesse caso, a "[...] performatividade marcada pelo princípio de ação (é um processo muito mais do que um objeto pronto). Assim, fazer é um dos primeiros princípios do performativo" (FÉRAL, 2009, p. 67). O teatro performativo envolve dessa forma um desempenho de ações e se apresenta aqui como algo que se "perfaz" diante do outro (RAMOS, 2015).

A partir dos estudos a respeito do conceito da performatividade, Féral percebe que, aliada a esse conceito, está a teatralidade. Como a própria autora aponta a "[...] performatividade pertenceria ao campo do fazer, lá onde a teatralidade revela a percepção desse fazer [...]. A teatralidade é então da ordem da percepção, lá onde o performativo se inscreve no fazer" (FÉRAL, 2009, p. 81).

Por muito tempo o entendimento do conceito de teatralidade esteve aliado ao texto e era isso que parecia diferenciar o teatro dos demais fenômenos artísticos. Contudo, o que a autora aponta é que a teatralidade não está apenas no teatro, mas pode ser observada também no cotidiano. A teatralidade é entendida aqui como "[...] um processo, uma produção relacionada sobretudo ao olhar que postula e cria outro espaço, tornado espaço do outro - espaço virtual, é claro - e dá lugar à alteridade dos sujeitos e a emergência da ficção" (FÉRAL, 2015, p. 86).

Dessa forma, o olhar que percebe a teatralidade cria uma clivagem, estabelecendo um outro espaço, um fora e um dentro, um espaço do outro, estabelecido por meio da "[...] identificação (quando é produzida pelo outro) ou a criação (quando o sujeito a projeta sobre as coisas) de um outro espaço, esse espaço diferente do cotidiano, criado pelo olhar do espectador que se mantém fora dele" (FÉRAL, 2015, p. 86). Desta maneira, a teatralidade é entendida como um

FAZZIONI, Mateus Junior ; BERSELLI, Marcia . O desenho da cena em um processo colaborativo: investigações acerca da cenografia performativa. Revista da FUNDARTE. Montenegro, p.01-22, ano 21, ํㅡ 46, setembro de 2021.

Disponível em: http://seer.fundarte.rs.gov.br/index.php/RevistadaFundarte/issue/archive $>30$ de setembro de 2021. 


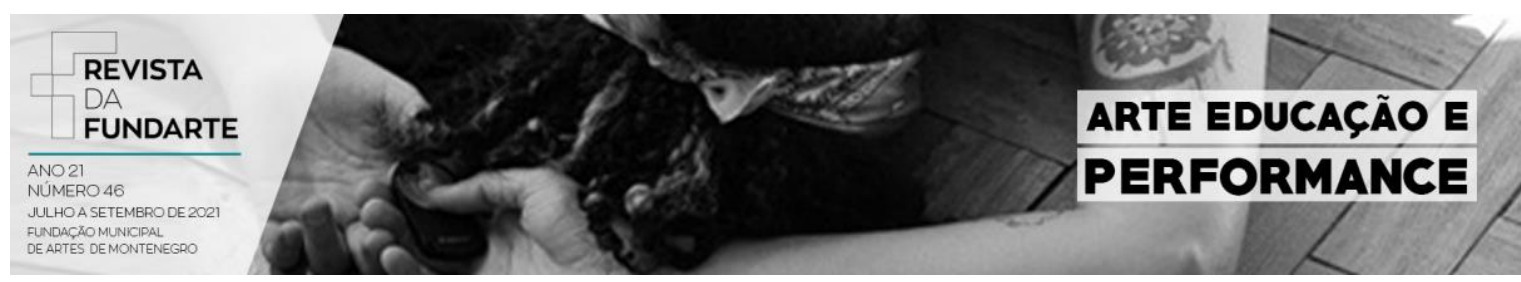

processo de "[...] operação cognitiva ou ato performativo daquele que olha (o espectador) e/ou daquele que faz (o ator)" (FERNANDES, 2011, p. 17).

Sendo assim, o teatro performativo se inscreve como ato do fazer, seja por conta do performer que por meio da performatividade performa ações e comportamentos restaurados, ou pelo olhar do espectador que confere a teatralidade como um ato por meio da sua percepção. A partir desses elementos performativos presentes no teatro, 0 teatro performativo tem como principais características e diferenças em relação ao teatro dramático:

[...] transformação do ator em performer, descrição dos acontecimentos da ação cênica em detrimento da representação ou de um jogo de ilusão, espetáculo centrado na imagem e na ação e não mais sobre o texto, apelo à uma receptividade do espectador de natureza essencialmente especular ou aos modos das percepções próprias da tecnologia. (FÉRAL, 2009, p. 198).

Se a ênfase desse teatro não está mais no texto dramático com o objetivo de criar uma ilusão por meio da representação, mas sim nas ações performativas desempenhadas pelo performer, isso pressupõe que esse último tenha responsabilidade. Assim, o performer tem responsabilidade de desempenhar o jogo entre as materialidades. Mas, é importante lembrar que segundo Féral (2009, p. 205) "[...] o objetivo do performer não é absolutamente o de construir ali signos cujo sentido é definido de uma vez por todas, mas de instalar a ambiguidade das significações, o deslocamento dos códigos, o deslizamento de sentido".

Deste modo, o que importa no teatro performativo não é o valor da representação de um único significado, mas sim o engajamento do corpo do performer no jogo cênico, evocando assim a performatividade. Tal performatividade presente na cena "[...] toma um lugar no real e enfoca essa mesma realidade na qual se inscreve desconstruindo-a, jogando com os códigos e as capacidades do espectador" (FÉRAL, 2009, 203). Assim, o que fica evidente a esse espectador é o desempenhar das ações, sendo que o corpo, o jogo e os repertórios técnicos do performer são colocados em primeiro plano.

FAZZIONI, Mateus Junior; BERSELLI, Marcia . O desenho da cena em um processo colaborativo: investigações acerca da cenografia performativa. Revista da FUNDARTE. Montenegro, p.01-22, ano 21, ํㅡ 46, setembro de 2021.

Disponível em: http://seer.fundarte.rs.gov.br/index.php/RevistadaFundarte/issue/archive $>30$ de setembro de 2021. 


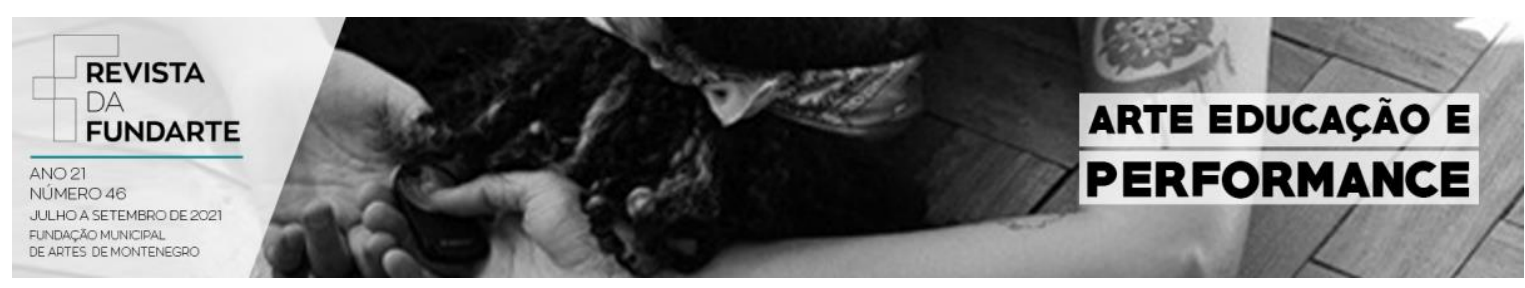

Estamos bem inseridos na performatividade do ator (e fora de um personagem), aquela da ação que se executa. O espectador é confrontado com este fazer, com estas ações postas [colocadas], das quais só lhe resta, a si próprio, encontrar o sentido. (FÉRAL, 2009, p. 202).

Dessa forma, não existe um único sentido a ser compreendido/percebido pelos espectadores, pelo contrário cada espectador tem a liberdade de criar os seus significados para as ações e da mesma forma enveredar pelas imagens que lhe são apresentadas, sem necessariamente dar um significado fechado a elas. Sendo assim, o rompimento da forma fechada, a quebra com a linearidade da narrativa, o desaparecimento da representação e da fábula, faz com que o convívio possa ser estabelecido com os espectadores e, consequentemente, leva a uma aproximação entre a cena e o cotidiano.

Além dessas características apresentadas, o modo de operação por meio do teatro performativo abre possibilidade para pensar e propor a criação em diferentes formas. Assim, pode-se pensar em trabalhos mais abertos e flexíveis, com hierarquias menos rígidas entre as funções criadoras e uma ênfase no processo e nas relações, como é o caso da operação no processo colaborativo.

O processo de criação em modo colaborativo: "Antes de falar já não se ouve"

O processo de criação do acontecimento cênico "Antes de falar já não se ouve" foi desenvolvido nas disciplinas de Montagem teatral do curso de Licenciatura em Teatro da UFSM no ano de 2019. O processo teve início em março e se desenvolveu durante o ano todo, tendo como ponto de partida uma conversa na qual a professora apresentou a disciplina e propôs a escolha entre alguns modos de operação e os estudantes, da mesma forma, levantaram alguns interesses individuais e coletivos a serem pesquisados - entre eles as funções, as temáticas e os recursos de criação.

Os pontos de vista levantados, mostravam um interesse comum do coletivo e da professora em trabalhar em uma perspectiva performativa, dando ênfase na ação e na performatividade dos elementos e corpos em cena. Além disso, fomos

FAZZIONI, Mateus Junior ; BERSELLI, Marcia . O desenho da cena em um processo colaborativo: investigações acerca da cenografia performativa. Revista da FUNDARTE. Montenegro, p.01-22, ano 21, ํㅡ 46, setembro de 2021.

Disponível em: http://seer.fundarte.rs.gov.br/index.php/RevistadaFundarte/issue/archive $>30$ de setembro de 2021. 


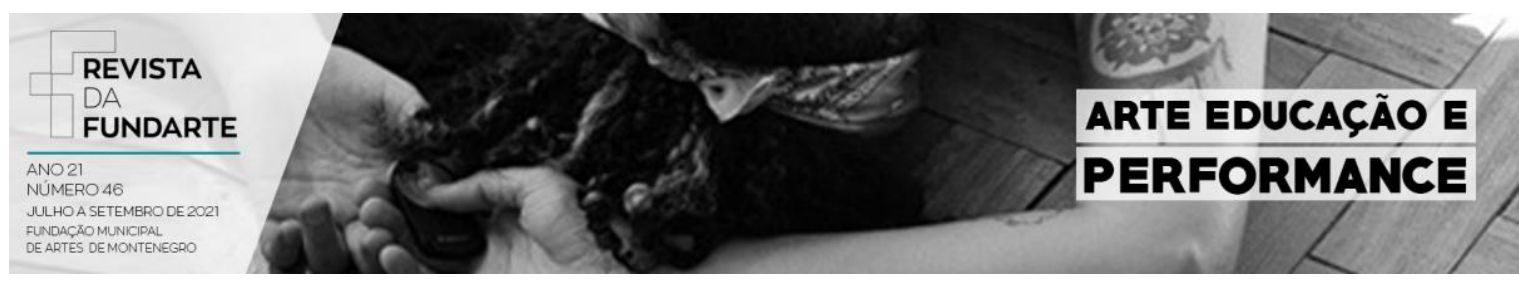

instigados a pensar em um tema que servisse de ponto inicial para o trabalho, e a partir disso em consenso optamos por explorar a temática das "opressões". Dentre as opções de modos de operação apresentados pela professora, optamos por uma prática mais aberta e flexível, em que cada um dos estudantes poderia ocupar uma ou mais funções criativas dentro do processo, de modo a desenvolver pesquisas de interesse durante a criação.

O processo foi estruturado a partir das funções como encenação, ocupada por três encenadoras; atuação contando com nove performers, sendo que esses ocupam também diferentes funções como (cenografia, figurino e maquiagem) ocupado por dois designers de cena; iluminação, ocupada por uma iluminadora; abordagem corporal, desempenhada por dois agentes; dramaturgia ocupada por duas dramaturgas e a produção desenvolvida por três pessoas do coletivo.

Assim, nos colocamos como criadores responsáveis não só pela atuação, mas também pelas demais funções como encenação, dramaturgia, produção, figurino, cenografia, maquiagem, iluminação e abordagem corporal. A partir desse desmembramento das funções e elementos do processo criativo concentrados em uma única pessoa, as funções artísticas foram divididas entre os vários criadores presentes no coletivo, e nesse caso matriculados na disciplina. $O$ processo se iniciou então sendo operado no modo colaborativo.

É importante deixar claro que o modo de operar no processo colaborativo se diferencia do processo coletivo no qual todos os integrantes se experimentam nas diferentes funções criadoras e elas são deixadas abertas até serem definidas. No colaborativo, as funções artísticas são escolhidas no início do processo por meio de um consenso, quando cada integrante ou convidado, a partir de suas habilidades e interesses direciona em que área artística quer se experimentar e desenvolver uma pesquisa no processo de criação (ARAÚJO, 2009).

Dessa forma o processo colaborativo se apresenta como uma metodologia de criação propondo uma horizontalidade entre as funções, na qual "[...] todos os integrantes, a partir de suas funções artísticas específicas, têm igual espaço

FAZZIONI, Mateus Junior ; BERSELLI, Marcia . O desenho da cena em um processo colaborativo: investigações acerca da cenografia performativa. Revista da FUNDARTE. Montenegro, p.01-22, ano 21, ํㅡ 46, setembro de 2021.

Disponível em: http://seer.fundarte.rs.gov.br/index.php/RevistadaFundarte/issue/archive $>30$ de setembro de 2021. 


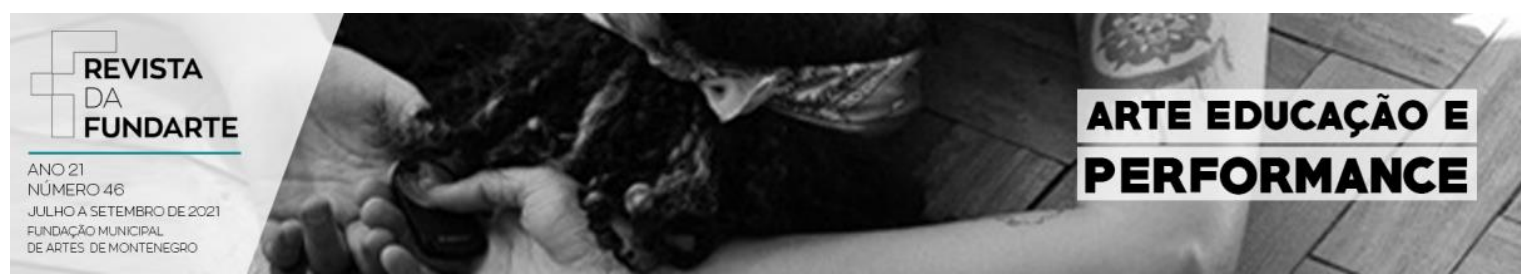

propositivo, produzindo uma obra cuja autoria é compartilhada por todos" (ARAÚJO, 2009 , p. 48). Sendo assim, se descentralizam as hierarquias no processo criativo e o poder de autoria sobre a obra sai das mãos de uma única pessoa e passa a ser compartilhado entre todos. A partir disso, todos as funções passam a ter autonomia, assumindo o mesmo poder de criação e proposição.

Contudo, não se trata de operar num processo sem hierarquias, mas sim de manusear as hierarquias do processo criativo, de modo que elas se desloquem entre as diversas funções através de um sistema que Araújo chama de "[...] hierarquias momentâneas ou flutuantes" (2009, p. 48). Nesse caso, entende-se que as hierarquias existem no processo por mais horizontal que esse seja, mas é preciso tomar decisões em determinados momentos, e assim as hierarquias flutuam entre as diferentes funções artísticas de modo a essas terem certa voz para fazerem suas escolhas na construção da cena.

Certamente esse modo de trabalho é muito complexo e pressupõe muita organização, diálogo entre as funções e responsabilidade sobre o processo. No caso do processo de criação de "Antes de falar já não se ouve", desde o início tentamos manter uma organização constante por meio do diálogo nos ensaios, investindo tempo para fazer as organizações e procurar soluções, visto que os integrantes não tinham experiência com esse modo de trabalho. Assim, pouco a pouco por meio da experiência compartilhada fomos compreendendo e nos afirmando como grupo em um processo colaborativo, repleto de responsabilidades, de negociações e de jogo entre os elementos e as funções criadoras.

Ao longo do processo, vimos o esfacelamento das estruturas hierarquizadas, para dar espaços às diferentes vozes criadoras, portadoras de referências e experiencias que se completam ou se tencionam no colaborativo e fazem o teatro acontecer. Um trabalho cênico que surgiu de um processo criativo pautado no diálogo entre os diversos sujeitos, elementos e linguagens e na responsabilidade dos criadores sobre esses aspectos.

FAZZIONI, Mateus Junior ; BERSELLI, Marcia . O desenho da cena em um processo colaborativo: investigações acerca da cenografia performativa. Revista da FUNDARTE. Montenegro, p.01-22, ano $21, n^{\circ}=46$, setembro de 2021.

Disponível em: http://seer.fundarte.rs.gov.br/index.php/RevistadaFundarte/issue/archive $>30$ de setembro de 2021. 


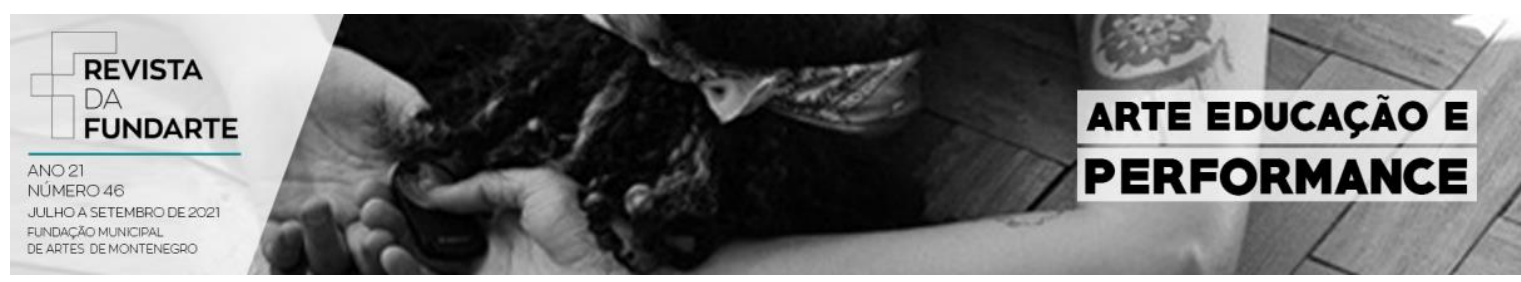

Desenvolver um processo colaborativo de criação envolve compreender nosso papel como agentes ativos, tanto em nossas funções individuais como colaboradores das outras funções artísticas e do processo como um todo. Todo esse envolvimento pressupõe responsabilidade de todos no gerenciamento da criação. Responsabilidade sobre os riscos e acertos, uma responsabilidade conjunta que faz o processo acontecer e que envolve a todos na lida com os problemas, demandas, tarefas e assuntos referentes à criação, produção e orçamento. Dessa forma, o que se estabelece no modo de operar do colaborativo é uma "[...] rede de interdependências que marca todo o processo" (ARAÚJO, 2009, p. 51).

Pensar essa responsabilidade em uma disciplina de um curso de graduação é diferente de pensá-la num processo fora do meio acadêmico. Conseguimos fazer algo muito difícil no contexto de uma disciplina por meio do diálogo e da organização, estabelecendo uma unidade colaborativa que depende de todos, para além das aulas, uma responsabilidade compartilhada e ao mesmo tempo individual.

\section{O designer de cena e o desenho da cena}

No processo de "Antes de falar já não se ouve", observou-se a possibilidade de pensar nas diversas funções artísticas da cena, em que cada criador por meio dos seus interesses poderia encontrar linhas de pesquisa e de trabalho. Há algum tempo vinha tendo o interesse de me aproximar das pesquisas com a estética da cena, e nesse processo houve a possibilidade de pesquisar a concepção da cenografia. Dessa forma, meus interesses como agente criativo do processo passaram a ser dois, a atuação e o desenho da cena, me colocando nas funções de ator/performer e designer de cena.

No primeiro momento, ainda não compreendia a minha pesquisa referente à estética da encenação como desenho da cena e não sabia muito bem que caminhos trilhar para conceber uma cenografia performativa. O objetivo era propor uma cenografia que pudesse se relacionar com o conceito de instalação, proposto pela arte contemporânea, objetos e elementos instalados no espaço com os quais os

FAZZIONI, Mateus Junior ; BERSELLI, Marcia . O desenho da cena em um processo colaborativo: investigações acerca da cenografia performativa. Revista da FUNDARTE. Montenegro, p.01-22, ano 21, ํㅡ 46, setembro de 2021.

Disponível em: http://seer.fundarte.rs.gov.br/index.php/RevistadaFundarte/issue/archive $>30$ de setembro de 2021. 


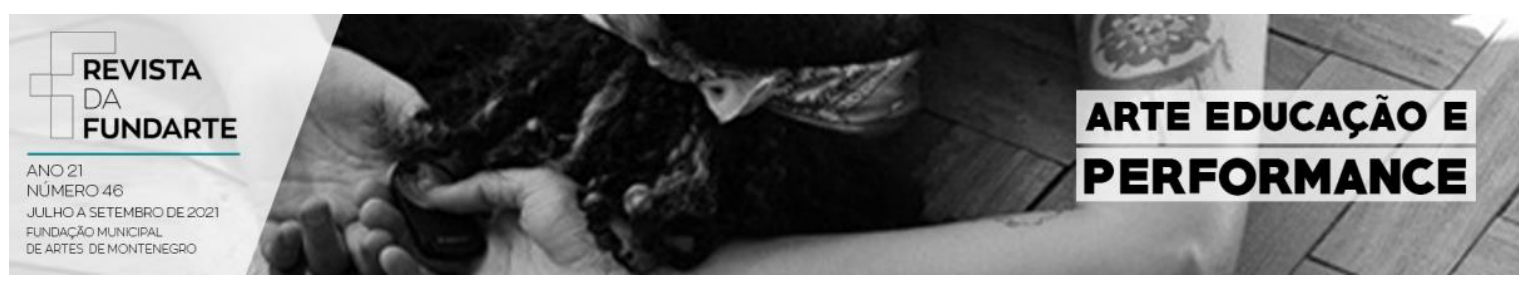

atores poderiam se relacionar e criar outras formas, transformando seus significados e sua utilidade na cena.

Buscando compreender as funções assumidas, tento contextualizar e deixar claro os conceitos empregados para o trabalho com a estética da cena. Dessa forma, compreende-se neste trabalho a cenografia, e os demais elementos da visualidade cênica, como o desenho da cena, que é concebido pelo artista designer de cena.

Falar sobre cenografia, é sobretudo levar em consideração a ética e estética de determinada cena. Por muito tempo a cenografia foi entendida apenas como pinturas tridimensionais que tinham como objetivo representar e simular determinados lugares, espaços e objetos criando uma teatralidade ao espectador. Foi, e ainda é em muitos casos, limitada a ser apenas um "[...] elemento narrativo, um auxiliar que permite situar espacial e temporalmente o tema abordado por um texto teatral ou por uma exposição" (ROSSINI, 2012, p. 158). Na contemporaneidade, em contrapartida, ela pode ser entendida como um conjunto composto por todas as visualidades cênicas, onde diversas linguagens artísticas se atravessam.

O conceito de cenografia que foi por muito tempo empregado "[...] para apontar a superficialidade de um lugar" (ROSSINI, 2012, p. 160), caminhou durante o século $X X$ ao lado de experiências cênicas totalmente contrárias a esse pensamento. No século em questão, artistas passaram a propor rupturas de padrões e formas, aproximando linguagens e estreitando fronteiras, assumindo a cenografia para além da ornamentação do espaço.

Adolphe Appia foi um dos primeiros a propor modificações na cenografia, tanto em questões estéticas, como também funcionais. Quando Appia propôs novas perspectivas para o teatro no início do século XX, apresentando várias modificações acerca do espaço, da dramaturgia, do ritmo e da presença cênica, pode-se então articular uma nova organização espacial para a cena.

FAZZIONI, Mateus Junior ; BERSELLI, Marcia . O desenho da cena em um processo colaborativo: investigações acerca da cenografia performativa. Revista da FUNDARTE. Montenegro, p.01-22, ano $21, n^{\circ}=46$, setembro de 2021.

Disponível em: http://seer.fundarte.rs.gov.br/index.php/RevistadaFundarte/issue/archive $>30$ de setembro de 2021. 


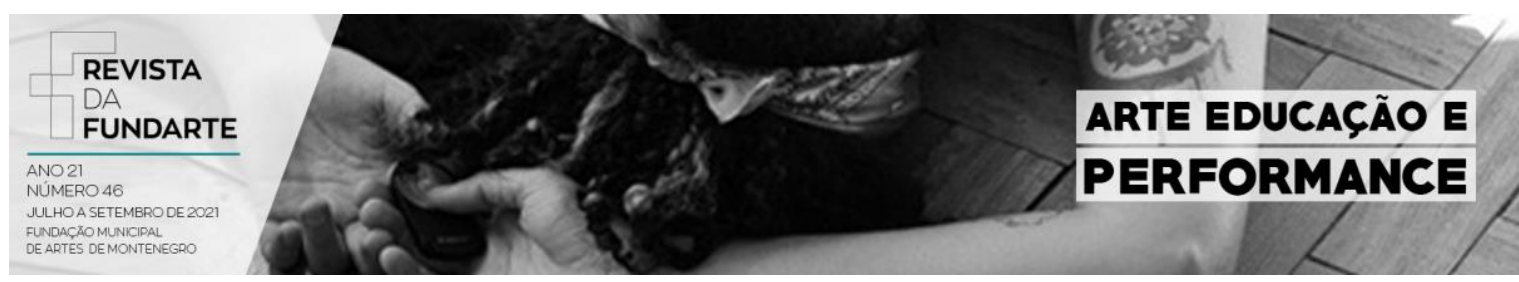

A partir da utilização de escadas, elevações, rampas e blocos tridimensionais, Appia buscou criar uma relação entre o espaço e o corpo do ator, onde este era obrigado a encontrar "[...] soluções plásticas e expressivas para agir sobre o espaço cenográfico" (ROSSINI, 2012, p. 159), modificando sua atuação e criando os espaços rítmicos. É a partir dessas proposições, rupturas e transformações da maneira de pensar a cenografia, que ao longo do século $X X$ muitos artistas por meio das suas inquietudes vão propor diversas perspectivas para o que chamamos hoje de desenho da cena.

O desenho da cena, é uma tradução que surge do conceito de performance design, e é tido aqui como uma experiência artística híbrida, em que algumas linguagens da arte se cruzam e se misturam na construção e elaboração do espaço performativo. A utilização dessa nomenclatura, segundo Cohen (2015, p. 02), tem "[...] o objetivo de estimular novas proposições na área da cenografia e afins", atentando para novos caminhos a serem percorridos, desconstruído padrões, reestruturando o espaço cênico, e propondo diferentes relações entre o indivíduo (ator/performer e espectador) com as materialidades da cena.

É possível compreender o desenho da cena como uma adaptação do que chamamos de cenografia, pensando nessa não como a reconstrução superficial de um lugar, mas sim como o conjunto das visualidades. A partir disso, entende-se que o desenho da cena é uma "[...] dimensão estética que trata de todos os aspectos visuais do Teatro e da Performance e perceptíveis na composição da cena, para além dos atores/performers e do texto" (COHEN, 2015, p. 02).

Pensar na construção do desenho de cena, não se trata apenas de um caráter estético, mas também ético. Isso porque, busca-se por meio da cenografia, da instalação e da expografia, enquanto elementos constituintes, que se atravessam e compõem o desenho da cena, provocar outras relações com os indivíduos e trabalhar a sua percepção e compreensão das visualidades para além da representação. Em virtude disso, a concepção do desenho da cena faz a intersecção entre várias expressões artísticas, e elementos das artes visuais, do teatro e da

FAZZIONI, Mateus Junior ; BERSELLI, Marcia . O desenho da cena em um processo colaborativo: investigações acerca da cenografia performativa. Revista da FUNDARTE. Montenegro, p.01-22, ano 21, ํㅡ 46, setembro de 2021.

Disponível em: http://seer.fundarte.rs.gov.br/index.php/RevistadaFundarte/issue/archive $>30$ de setembro de 2021. 


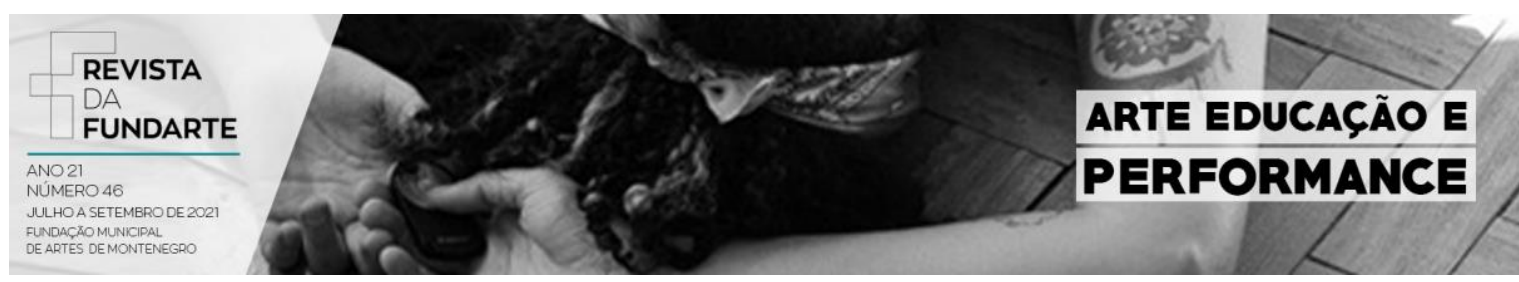

performance, a fim de ressignificar e transformar objetos, espaços, relações e consequentemente a própria ação.

[...] o conceito desenho da cena emerge, portanto para reforçar a noção de hibridismo como qualidade da produção do artista cenógrafo ou designer de cena que atua no ENTRE. Hibridismo como um leque que reúne um amplo espectro de modalidades artísticas visuais, sensoriais e por vezes também arquitetônicas. (COHEN, 2015, p. 10).

Diante disso, é possível pensar no desenho da cena como uma forma de expressão do artista responsável por tal função em um processo criativo, no qual ele desenvolve a criação e a elaboração de uma cenografia multidisciplinar e híbrida.

Para pensar na elaboração e organização de um espaço, é preciso primeiramente compreender o conceito de espaço, e isso é sem dúvida uma das tarefas do designer de cena enquanto profissional responsável pelo desenho da cena. O termo designer de cena é utilizado aqui "[...] para fazer referência ao artista que desenha a cena. O termo em inglês "Designer" é utilizado porque já é um termo identificado em nossa cultura" (COHEN, 2015, p. 08, grifo nosso). Dentre as funções que integram o processo de criação artística do designer pode-se citar:

[...] a percepção e a compreensão acerca de um espaço, desenhar um espaço, ocupá-lo, criar elementos visuais que dialoguem estética e fisicamente com o espaço, entender a dinâmica e a suas possibilidades de recomposição, além das incidências naturais e criadas da cor, luz e som. (COHEN, 2015, p. 18).

Ou seja, é função do artista designer de cena criar a composição visual do espaço por meio da criação do desenho da cena. Por ser entendido como um artista autônomo, o designer pode mesclar em suas obras diferentes linguagens, materiais, elementos, promovendo tensionamentos entre o real e o ficcional. Ele é responsável por articular uma espécie de abrigo para o desenvolvimento do acontecimento cênico, buscando a interação entre as questões do espaço, da ação e da recepção (COHEN, 2015, p. 07).

O designer de cena é responsável por imaginar e materializar por meio de sua liberdade criativa os aspectos visuais da cena e propor relações entre o indivíduo e a

FAZZIONI, Mateus Junior; BERSELLI, Marcia . O desenho da cena em um processo colaborativo: investigações acerca da cenografia performativa. Revista da FUNDARTE. Montenegro, p.01-22, ano 21, ํㅡ 46, setembro de 2021.

Disponível em: http://seer.fundarte.rs.gov.br/index.php/RevistadaFundarte/issue/archive $>30$ de setembro de 2021. 


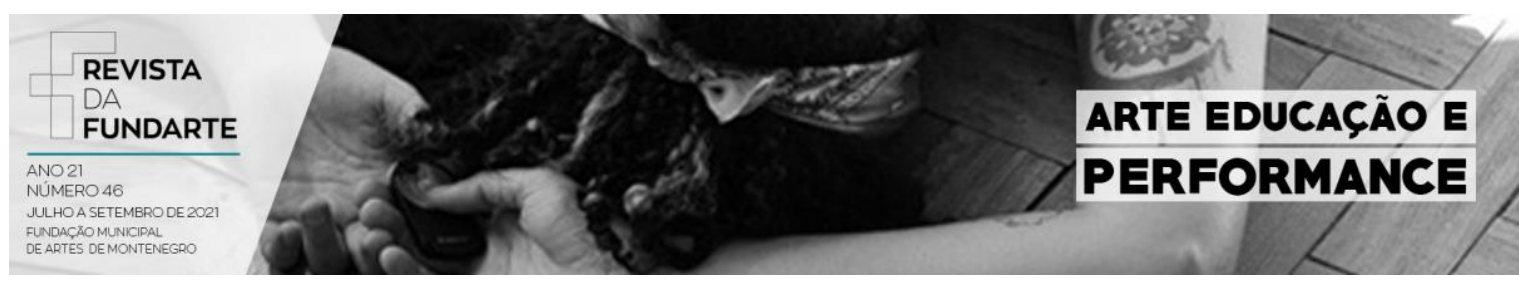

obra cenográfica, seja por meio da percepção do espaço, ou da manipulação e habitação dos elementos e materiais que compõem esse espaço. Ele tem a liberdade de implicar as suas experiências, conhecimentos e interesses na criação de sua obra cenográfica, instalada e exposta no espaço cênico.

A exploração das funções artísticas por meio de workshops

A partir da compreensão da minha função enquanto designer de cena e aliando a isso as minhas experiências artísticas e os meus interesses de pesquisa no processo colaborativo, o processo de criação de "Antes de falar já não se ouve" se iniciou por meio de explorações e improvisações com alguns recursos sensíveis ${ }^{4}$, das quais resultaram muitas cenas a serem retomadas, ressignificadas e potencializadas durante o processo.

A criação com os recursos nos mostrou um primeiro caminho a seguir, no processo colaborativo, e nos auxiliou na construção do Projeto de Montagem Teatral atentando para todas as funções criativas, projetando objetivos, proposições e perspectivas. A partir da apresentação e compartilhamento desse projeto entre as diversas vozes criadoras, identificamos que poderíamos aproximar do nosso processo colaborativo algumas características do Devised Theatre (ODDEY, 1994).

O devising surgiu nos anos 60 e 70, período histórico já apontado neste estudo como uma época marcada pelos questionamentos da produção da arte e, também, do surgimento de práticas teatrais experimentais. Nesse contexto, nascem práticas de criação colaborativas, que podem ser desenvolvidas sem a utilização de um texto dramático.

Em muitos casos, Devised Theatre é traduzido para o português como "processo colaborativo", contudo neste estudo não se entende os dois conceitos com o mesmo significado, visto que "[...] o devised pode ser uma criação colaborativa, mas não necessariamente deve ser" (MESQUITA, 2012, p. 109). Isso porque

\footnotetext{
${ }^{4}$ A utilização dos recursos sensíveis faz referência ao Cycles Repère desenvolvido por Jacques Lessard e "trata-se de um recurso que toque o criador, que o impulsione à criação". (BERSELLI et al., 2018, p. 101).
}

FAZZIONI, Mateus Junior; BERSELLI, Marcia . O desenho da cena em um processo colaborativo: investigações acerca da cenografia performativa. Revista da FUNDARTE. Montenegro, p.01-22, ano 21, ํㅡ 46, setembro de 2021.

Disponível em: http://seer.fundarte.rs.gov.br/index.php/RevistadaFundarte/issue/archive $>30$ de setembro de 2021. 


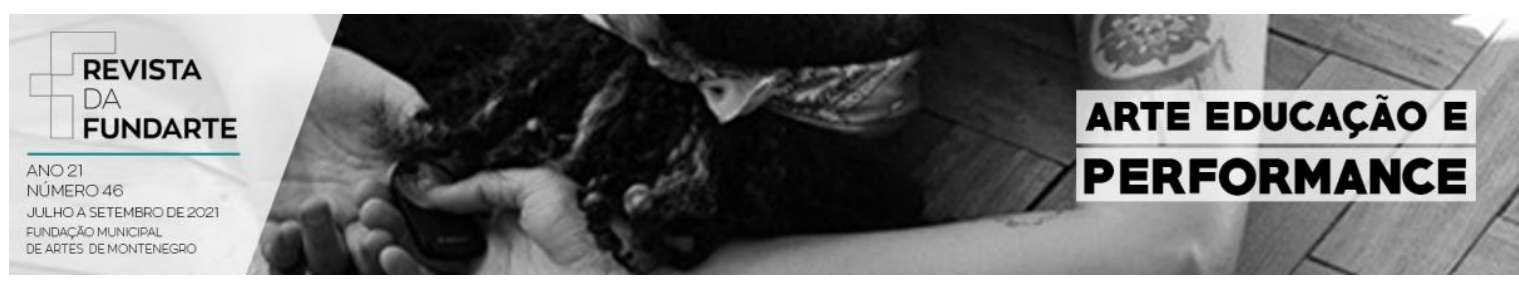

devising performance, por exemplo, pode ser desenvolvido de maneira solo e não envolver colaboradores. E além disso, a tradução literal desse termo "[...] significa teatro 'feito' ou 'criado', e assim pode ser entendido como uma prática teatral onde o espetáculo é resultado do material criado durante o processo de montagem" (MESQUITA, 2012, p. 104).

O método do Devising Theatre pode se desenvolver por meio de workshops criativos em que se exploram improvisações, textos dramáticos, não dramáticos, uma ideia antecipada ou uma questão que perpassa o coletivo. A partir dessa compreensão, percebeu-se que em nosso processo colaborativo era pertinente utilizar os workshops criativos, não para explorar um texto ou uma questão, mas sim como uma forma de proporcionar espaços de criação, com estímulos e elementos sendo apresentados para os agentes criativos e a partir dos quais eles improvisaram de modo a estabelecer cenas e composições.

A partir disso, alguns ensaios foram dedicados para os workshops, nos quais exploramos as diversas linguagens cênicas e em que cada agente artístico poderia ser propositivo a partir de sua função artística de modo a estabelecer uma exploração e um jogo de improvisação dos atores/performers com os elementos, objetos, textos, iluminação, sonoplastia etc.

A partir desse espaço de proposição aberto a cada um dos agentes criativos por meio dos workshops, me colocando enquanto artista designer de cena, propus explorações e improvisações com materiais como caixas de papelão, papel pardo, espelhos, figurinos etc. Esse momento de exploração foi importante para gerar interações entre os atores/performers e as materialidades e da mesma forma começar a esboçar o desenho da cena, a fim de espacializar os elementos visuais e deixá-los instalados no espaço para o jogo com os agentes criativos.

Durante esse momento de exploração fui percebendo diversos materiais criados por meio da improvisação, com os atores/performers buscando interagir com os elementos de outras formas, modificando suas funções e assim ressignificando

FAZZIONI, Mateus Junior; BERSELLI, Marcia . O desenho da cena em um processo colaborativo: investigações acerca da cenografia performativa. Revista da FUNDARTE. Montenegro, p.01-22, ano 21, no 46, setembro de 2021.

Disponível em: http://seer.fundarte.rs.gov.br/index.php/RevistadaFundarte/issue/archive $>30$ de setembro de 2021. 


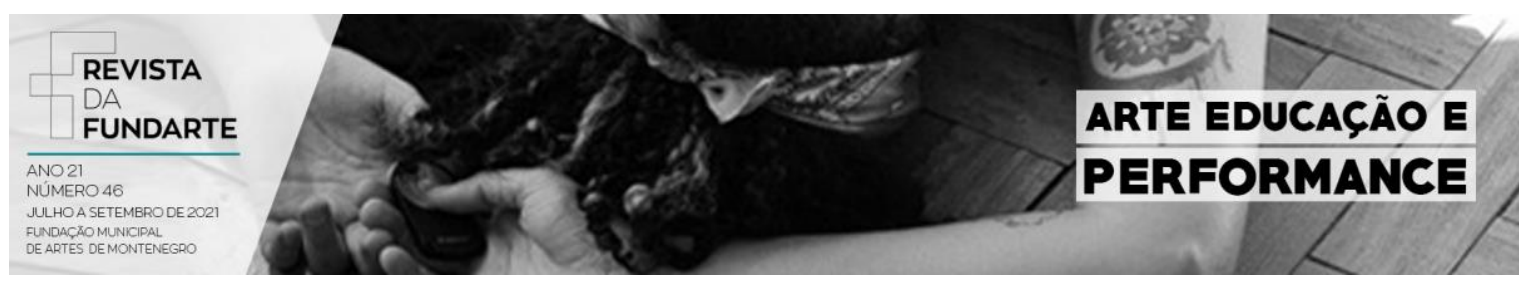

os seus discursos e significados. A partir dessas criações, passei a perceber que havia muito material a ser explorado e articulado na criação do desenho da cena.

Mas, nesse contexto, alguns questionamentos se fizeram presentes, pensando na relação entre a criação dos agentes com os elementos propostos e as minhas ideias e projeções enquanto artista designer de cena. Apesar de ter a voz final sobre o desenho da cena, como a minha figura de designer de cena manuseia, agencia, recorta e faz a organização e construção do espaço, pensando num processo colaborativo, operado por meio de workshops em que todos se relacionam e estabelecem muitas relações interessantes com os elementos? Como conciliar o que eu acho pertinente e interessante para a cena, com o novo que surge nas criações?

No primeiro momento foi difícil encontrar respostas para esses questionamentos, mas percebi que assumir o desenho da cena como uma experiência era uma das alternativas para se pensar numa cenografia performativa que está em constante transformação. Isso porque, o espaço performativo, aberto por meio da estética e da ética implicadas ao processo criativo, possibilitou inserir os elementos componentes do desenho da cena, expostos e instalados no espaço, em uma experiência, que é tida aqui como "[...] um encontro entre o corpo em movimento no lugar e em relação ao espaço do evento" (COHEN, 2015, p. 97).

$O$ teatro performativo, ao privilegiar a performatividade, instaura um espaço performativo, onde as ações irão se desenvolver. Dentro desse espaço, o designer de cena fica responsável pela elaboração de um desenho para a cena, e a partir desse desenho, uma cenografia composta por elementos, materialidades e visualidades é instalada e exposta no espaço. O fato é que, no processo de construção do acontecimento cênico "Antes de falar já não se ouve", o desenho da cena que foi elaborado não é uma articulação apenas das ideias do designer, mas sim, surge das experiências interativas entre os performers, os elementos, o espaço e o tempo.

FAZZIONI, Mateus Junior; BERSELLI, Marcia . O desenho da cena em um processo colaborativo: investigações acerca da cenografia performativa. Revista da FUNDARTE. Montenegro, p.01-22, ano 21, ํㅡ 46, setembro de 2021.

Disponível em: http://seer.fundarte.rs.gov.br/index.php/RevistadaFundarte/issue/archive $>30$ de setembro de 2021. 

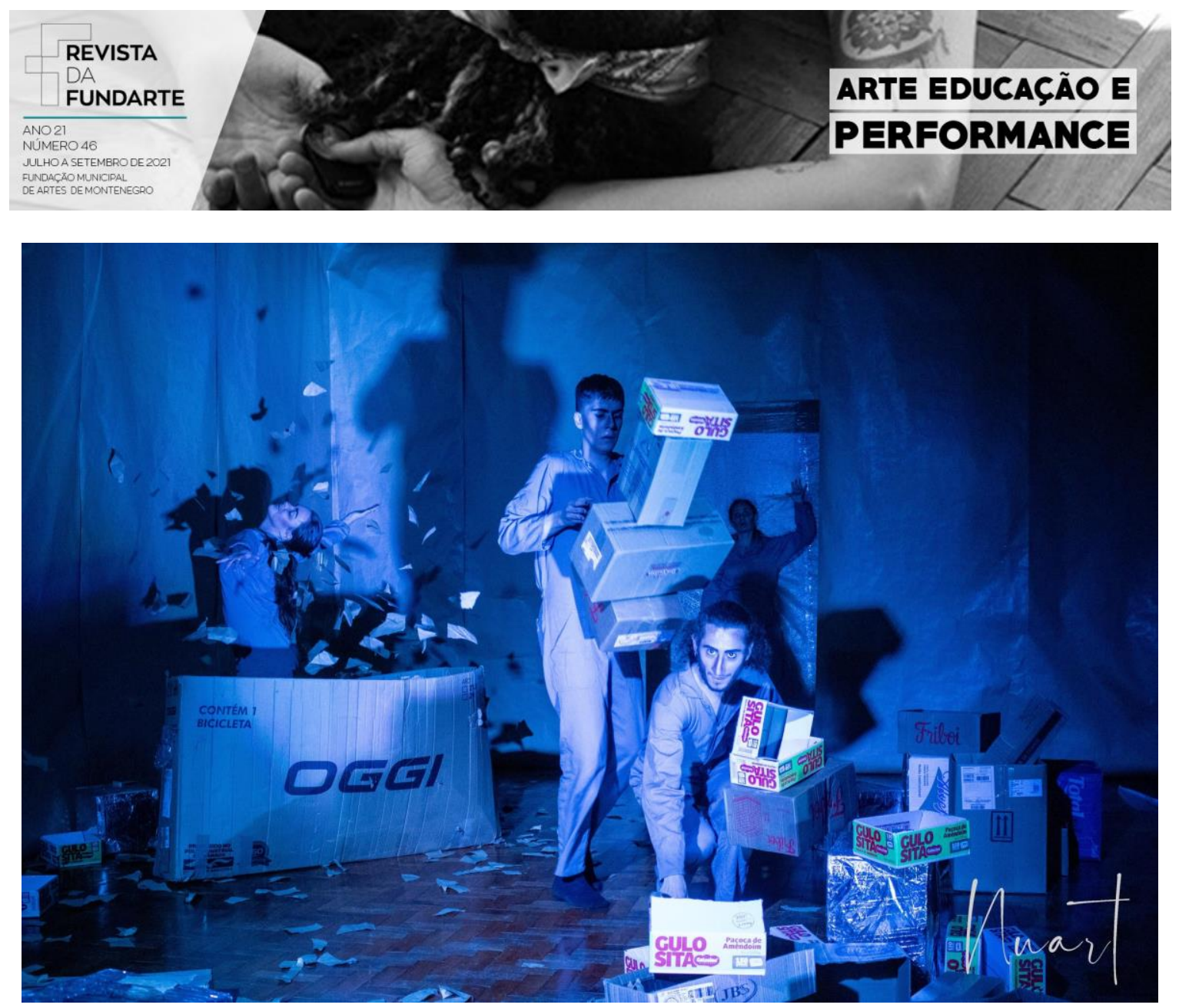

FIGURA 1 - Acontecimento cênico “Antes de falar já não se ouve”. 2019. Foto: Carolina Navarrina Gutierrez (Nuart)

Enquanto designer de cena tive a responsabilidade de elaborar, a partir dos materiais criados nas improvisações e a partir das minhas ideias enquanto artista criador, um desenho da cena. Contudo, ele é tido como experiência, enfatizando "[...] a condição do desenho como um jogo de elementos em composição que conduzem a uma vivência" (COHEN, 2015, p. 98) entre os corpos (atores e espectadores) que habitam esse espaço performativo.

Ao ser finalizada enquanto desenho, a cenografia que foi então instalada no espaço performativo da cena passou a ganhar vida e movimento em virtude dos corpos que a habitavam. Por meio da presença, das ações e dos movimentos os corpos manipulam e transformam o desenho da cena, modificando seus significados, seus discursos e sua utilidade, implicando performatividade aos elementos expostos e instalados e da mesma forma fazendo surgir novas relações e ações no momento presente do acontecimento.

FAZZIONI, Mateus Junior ; BERSELLI, Marcia . O desenho da cena em um processo colaborativo: investigações acerca da cenografia performativa. Revista da FUNDARTE. Montenegro, p.01-22, ano 21, no 46, setembro de 2021.

Disponível em: http://seer.fundarte.rs.gov.br/index.php/RevistadaFundarte/issue/archive > 30 de setembro de 2021. 


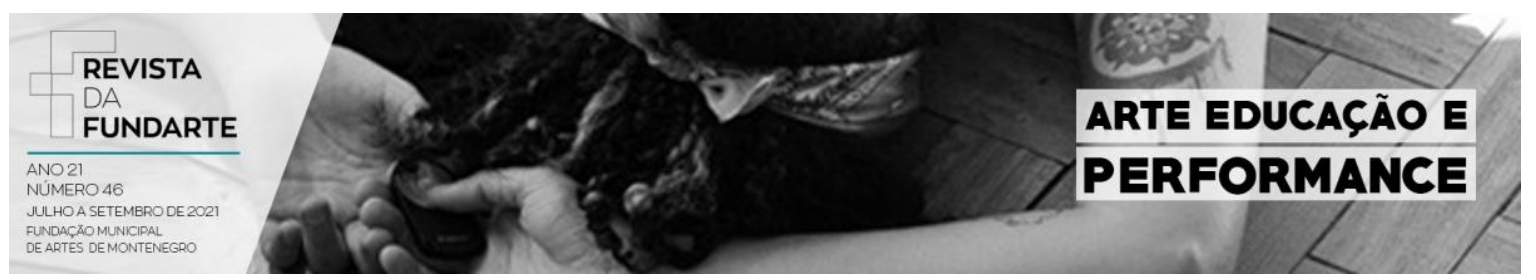

Essa interatividade entre os corpos e os elementos que proporciona ao desenho da cena uma performatividade, e que dá movimento à cenografia transformando-a também em performativa, proporciona a essa um constante processo de transformação. Isso porque, a cada compartilhamento do acontecimento cênico, o jogo entre corpos, elementos, espaço e tempo se refaz e assim novas relações, discursos e significados surgem, ou são potencializados, fazendo com que a cenografia esteja também sempre em vias de se re-fazer.

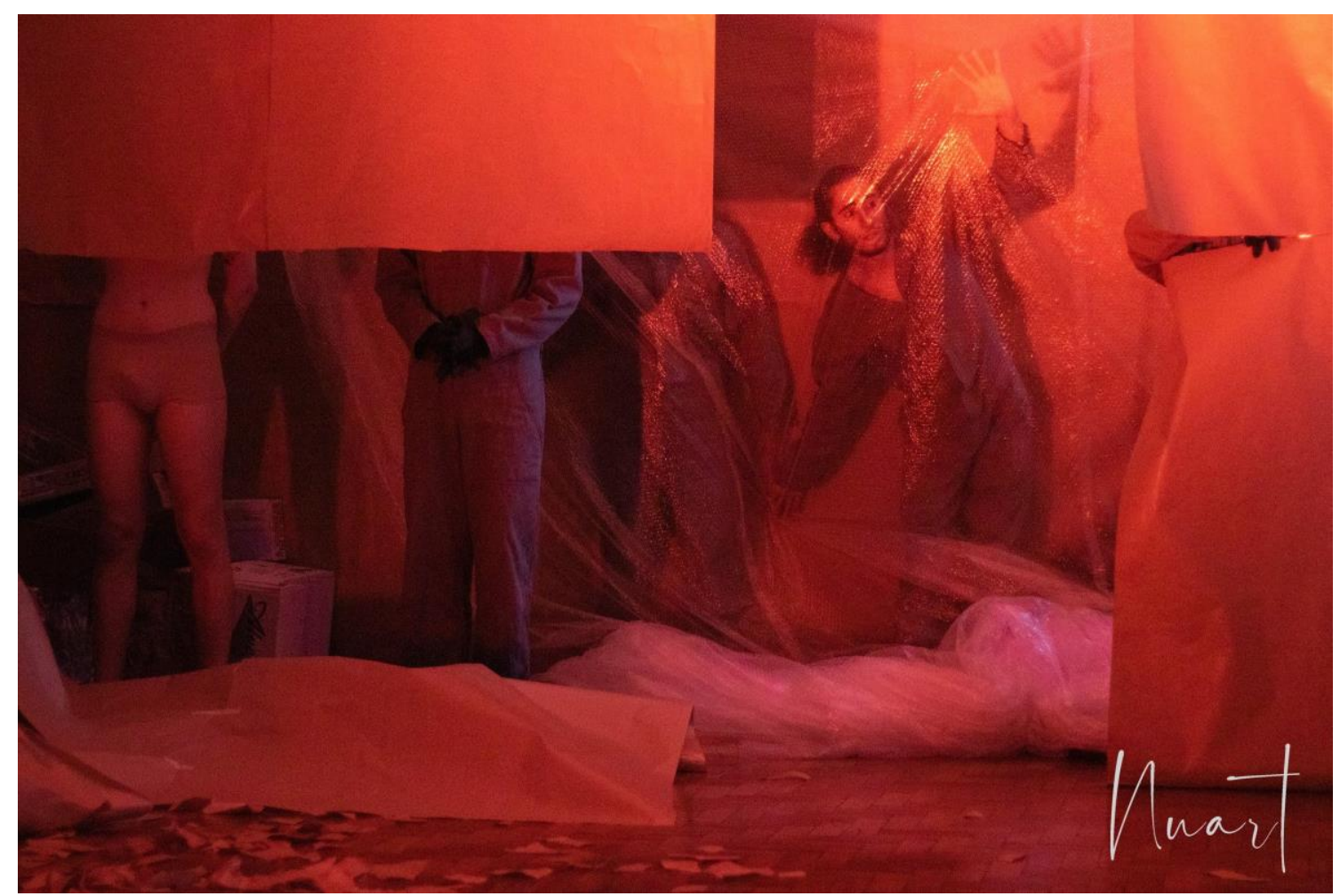

FIGURA 2 - Acontecimento cênico "Antes de falar já não se ouve”. 2019. Foto: Carolina Navarrina Gutierrez (Nuart)

Considerações finais

Ao se tornar performativa, a cenografia do acontecimento cênico em questão, deixou de ser apenas útil e passou a ser um importante elemento estético, colaborando com a construção da poética da cena, uma vez que em sua elaboração, conseguimos atravessar o material criado pelos atores nas improvisações, a voz

FAZZIONI, Mateus Junior; BERSELLI, Marcia . O desenho da cena em um processo colaborativo: investigações acerca da cenografia performativa. Revista da FUNDARTE. Montenegro, p.01-22, ano 21, № 46, setembro de 2021.

Disponível em: http://seer.fundarte.rs.gov.br/index.php/RevistadaFundarte/issue/archive $>30$ de setembro de 2021. 


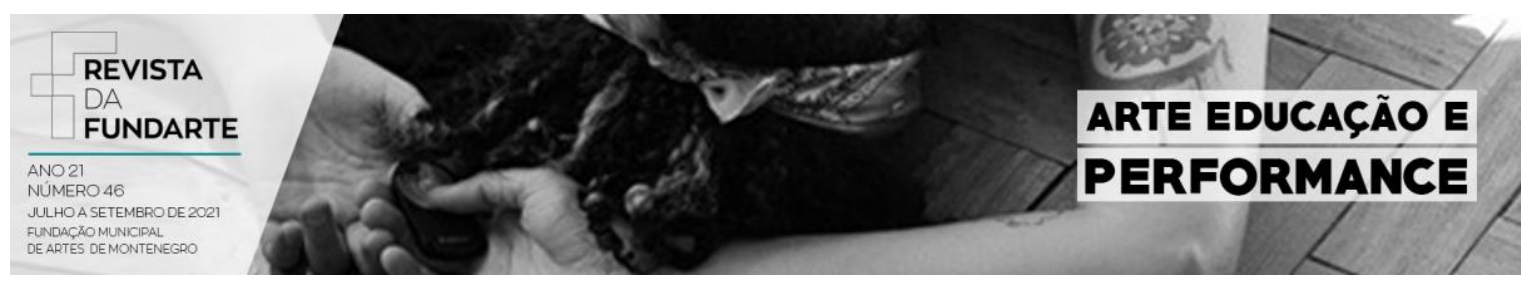

artística do designer criador e ao mesmo tempo oferecer lacunas para novas transformações que hão de surgir.

Sendo assim, assumimos que mesmo finalizado, o desenho da cena continua em experiência, sendo complementado a cada compartilhamento pela atualização da ação do ator/performer e, por fim, pelo olhar do espectador. Dessa forma, o espaço da cena é entendido como um processo onde se estabelecem as relações entre os diferentes corpos (atores e espectadores) e os espaços compartilhados por esses.

Enfim, ao assumirmos uma cena tomada não só por diferentes vozes criadoras, mas pela performatividade e pela teatralidade, em seus elementos constituintes, estamos instaurando "[...] um espaço onde a recepção torna-se mais complexa" e a cenografia "[...] um dispositivo espacial que introduz novos estímulos que desafiarão a percepção do indivíduo" (RODRIGUES, 2016, p. 100).

Sendo assim, se reconhece o potencial performativo que a cenografia pode assumir na cena contemporânea, deixando de ser um espaço apenas útil na construção da narrativa, para se tornar também um espaço da ação, privilegiando as experiências entre os diferentes corpos, elementos e espaços reais e ficcionais. Dessa forma, abre-se possibilidade para se pensar em cenas híbridas, compostas por elementos autônomos e propositivos, nas quais é possível misturar o teatro, as artes visuais, a dança, a performance, a instalação e até mesmo a exposição numa experiência que priorize a performatividade do espaço em relação aos corpos.

Tais apontamentos sobre a performance do espaço abrem brechas para se pensar no polimorfismo da cena contemporânea como possibilidade de propor experiências artísticas mais imersivas e sensíveis, que priorizam o fazer compartilhado do teatro e seu caráter ético, estético e político como emancipação das diferentes vozes criadoras.

FAZZIONI, Mateus Junior ; BERSELLI, Marcia . O desenho da cena em um processo colaborativo: investigações acerca da cenografia performativa. Revista da FUNDARTE. Montenegro, p.01-22, ano $21, n^{\circ}=46$, setembro de 2021.

Disponível em: http://seer.fundarte.rs.gov.br/index.php/RevistadaFundarte/issue/archive $>30$ de setembro de 2021. 


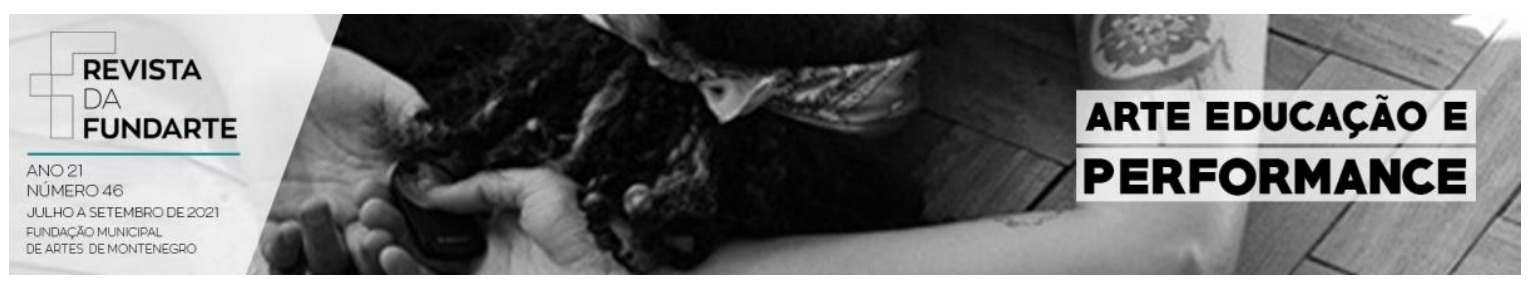

\section{Referências:}

ARAÚJO, Antônio. O processo colaborativo como modo de criação. Revista Olhares, São Paulo, n. 01, 2009. Disponível em: http://www.celiahelena.com.br/olhares/index.php/olhares/article/view/8/8. Acesso em: 19 nov. 2019.

BERSELLI, Marcia et al. Processo colaborativo e a busca pela horizontalidade das relações entre as funções da cena: procedimentos, práticas e estratégias de criação. Conceição/Conception, Campinas, v. 7, n. 2, 2018. Disponível em: https://periodicos.sbu.unicamp.br/ojs/index.php/conce/article/view/8650145/19001.

Acesso em: 20 dez. 2019.

COHEN, Miriam Aby. O desenho da cena como experiência: intersecções na prática artística contemporânea entre cenografia instalação expografia. 2015. Tese (Doutorado em Teoria e Prática do Teatro) - Escola de Comunicações e Artes, Universidade de São Paulo, São Paulo, 2015.

FÉRAL, Josette. Além dos limites: teoria e prática do teatro. São Paulo: Perspectiva, 2015. 224 p.

Performance e performatividade. In: MOSTAÇO, Edélcio, OROFINO, Isabel, BAUMGÄRTEL, Stephan, COLLAÇO, Vera. Sobre Performatividade. Florianópolis: Letras Contemporâneas, 2009. 272 p.

. Por uma poética da performatividade: o teatro performativo. Sala Preta, São Paulo, v. 8, 2009. Disponível em: http://www.revistas.usp.br/salapreta/article/view/57370/60352. Acesso em: 19 nov. 2019.

FERNANDES, Silvia. Teatralidade e Performatividade na Cena Contemporânea. Repertório, Salvador, n. 16, 2011. Disponível em: https://portalseer.ufba.br/index.php/revteatro/article/view/5391/3860. Acesso em: 19 nov. 2019.

LEHMANN, Hans-Thies. Teatro pós-dramático. São Paulo: Cosac Naify, 2007. 440 p.

Teatro pós-dramático e processos de criação e aprendizagem da cena: um diálogo com Hans-Thies Lehmann. Revista Aspas. São Paulo, v. 31, n. 02, 2013. Disponível em: http://www.revistas.usp.br/salapreta/article/view/69094/71540. Acesso em: 19 nov. 2019.

FAZZIONI, Mateus Junior; BERSELLI, Marcia . O desenho da cena em um processo colaborativo: investigações acerca da cenografia performativa. Revista da FUNDARTE. Montenegro, p.01-22, ano 21, ํㅡ 46, setembro de 2021.

Disponível em: http://seer.fundarte.rs.gov.br/index.php/RevistadaFundarte/issue/archive $>30$ de setembro de 2021. 


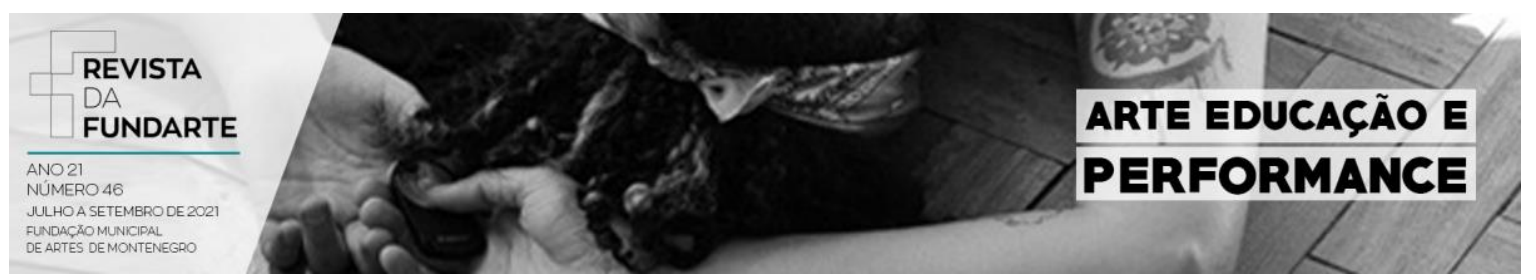

MESQUITA, Priscila de Azevedo Souza. Em busca de um teatro feminista: relatos e reflexões sobre o processo de criação do texto e espetáculo "Jardim de Joana". 2012. Dissertação (Mestrado em teatro) - Universidade do Estado de Santa Catarina, Florianópolis, 2012.

ODDEY, Alison. Devising Theatre: a practical and theoretical handbook. London: Routledge, 1994. 254 p.

RAMOS, Luiz Fernando. Mimesis Performativa. A Margem de Invenção Possível. São Paulo: Anna Blume, 2015. 290 p.

RODRIGUES, Cristiano Cezarino. O campo ampliado da teatralidade performativa na cenografia contemporânea. O Percevejo, Rio de Janeiro, v. 8, n. 1, 2016. Disponível em: http://www.seer.unirio.br/index.php/opercevejoonline/article/view/4056/5210. Acesso em: 19 nov. 2019.

ROSSINI, Élcio. Cenografia no teatro e nos espaços expositivos: uma abordagem além da representação. TransInformação, Campinas, v. 24, n. 3, 2012. Disponível em: http://www.scielo.br/pdf/tinf/v24n3/a01v24n3. Acesso em: 19 nov. 2019.

SCHECHNER, Richard. Performance Studies: an introduction. New York, USA: Routledge, 2006. $368 \mathrm{p}$.

FAZZIONI, Mateus Junior; BERSELLI, Marcia . O desenho da cena em um processo colaborativo: investigações acerca da cenografia performativa. Revista da FUNDARTE. Montenegro, p.01-22, ano 21, no 46, setembro de 2021.

Disponível em: http://seer.fundarte.rs.gov.br/index.php/RevistadaFundarte/issue/archive $>30$ de setembro de 2021. 